\title{
Gene Transfer of CD40-Ligand Induces Autologous Immune Recognition of Chronic Lymphocytic Leukemia B Cells
}

\author{
Kazunori Kato, Mark J. Cantwell, Sanjai Sharma, and Thomas J. Kipps \\ Division of Hematology/Oncology, Department of Medicine and the UCSD Human Gene Therapy Program, UCSD School of Medicine, \\ La Jolla, California 92093-0663
}

\begin{abstract}
CD40-CD40-ligand (CD154) interactions play a critical role in immune activation. Using replication defective adenovirus encoding mouse CD154 (Ad-CD154), we modified human chronic lymphocytic leukemia B cells to express a functional ligand for CD40. This not only induces expression of immune accessory molecules on the infected cell, but also allows it to trans-activate noninfected bystander leukemia B cells. Also, factors that impair the antigen-presenting capacity of leukemia B cells are downmodulated. Ad-CD154infected leukemia cells are highly effective stimulators in mixed lymphocyte reactions and can induce generation of cytotoxic $T$ lymphocytes specific for autologous nonmodified leukemia cells. As such, Ad-CD154 can induce a host antileukemia response that may have therapeutic potential. (J. Clin. Invest. 1998. 101:1133-1141.) Key words: CD40ligand $\bullet$ leukemia $\cdot$ antigen presentation $\bullet$ immune activation - gene therapy

\section{Introduction}

B cell chronic lymphocytic leukemia $(\mathrm{CLL})^{1}$ is an accumulative disease of slowly dividing, monoclonal B cells that express differentiation antigens, class I and II molecules of the MHC, and surface $\operatorname{Ig}(1,2)$. The Ig expressed in this disease, although often encoded by nonmutated Ig variable region genes, has features that distinguish it from the Ig expressed by normal, nonmalignant B cells $(3,4)$. Furthermore, CLL B cells frequently harbor complex cytogenetic abnormalities that often accumulate over time $(1,2,5-8)$. In view of the CLL B cell's slow growth kinetics, expression of MHC class I and II mole-
\end{abstract}

\footnotetext{
Address correspondence to Thomas J. Kipps, Department of Medicine and the UCSD Human Gene Therapy Program, UCSD School of Medicine, 9500 Gilman Dr., La Jolla, CA 92093-0663. Phone: 619534-5417; FAX: 619-534-5620; E-mail: tkipps@ucsd.edu

Received for publication 12 August 1997 and accepted in revised form 21 January 1998.
}

1. Abbreviations used in this paper: APCs, antigen-presenting cells; CLL, chronic lymphocytic leukemia; CTL, cytotoxic T lymphocyte; MFIR, mean fluorescence intensity ratio; MLTR, mixed lymphocyte reactions; PE, phycoerythrin; PI, propidium iodide.

J. Clin. Invest.

(C) The American Society for Clinical Investigation, Inc. 0021-9738/98/03/1133/09 \$2.00

Volume 101, Number 5, March 1998, 1133-1141

http://www.jci.org cules, and propensity to express proteins that distinguish it from other somatic cells, including normal B lymphocytes, the leukemia B cells should be susceptible to host immune recognition.

However, despite expressing MHC class II molecules, CLL $B$ cells are ineffective antigen-presenting cells (APCs). These leukemia cells are unable to stimulate $\mathrm{T}$ cells in allogeneic mix lymphocyte reactions, in part because they lack expression of important costimulatory accessory molecules necessary for efficient $\mathrm{T}$ cell activation (9-11). Furthermore, leukemic B cells can downmodulate the levels of stimulatory $\mathrm{T}$ cell surface molecules that are induced in response to antigen (12). For these reasons, it may be necessary to change the phenotype of the leukemia B cell to stimulate a host antileukemia immune response.

Exposure of leukemia cells to sufficient numbers of activated T cells can induce dramatic changes in the CLL cell surface phenotype within 48-72 h (9). The signals are mediated largely by members of the TNF family of ligands and receptors expressed on activated $\mathrm{T}$ cells and leukemic B cells, respectively. A critical surface molecule is the ligand for CD40 (CD154), a class II membrane glycoprotein (9-11, 13-16). This molecule is expressed transiently on $\mathrm{CD}^{+} \mathrm{T}$ cells within $4 \mathrm{~h}$ after ligation of the $\mathrm{T}$ cell receptor CD3 complex, and then is rapidly downmodulated (12,17-19). Expression of CD154 allows activated $\mathrm{T}$ cells to stimulate CD40-bearing $\mathrm{B}$ cells, monocytes, and dendritic cells into expressing other immune accessory surface molecules that are important in cognate costimulatory cell-cell interactions (9-11, 20-22). Activated T cells also can engage CD40 on the leukemia B cell surface. This, along with signals derived from TNF itself, triggers a cascade of events that ultimately results in the leukemia cell expressing a variety of heretofore nonexpressed stimulatory surface accessory molecules, such as CD80 (B7-1). Such changes allow the leukemic cell to stimulate allogeneic nonactivated $\mathrm{T}$ cells to respond productively to presented antigens, potentially also to those peculiar to the leukemia cell clone.

To extend these findings into a practical and efficient strategy for immune therapy of CLL, we examined whether CLL B cells could express genes encoding a functional ligand for CD40. Previously we found that high proportions of CLL B cells from any one patient could be made to express a selected transgene using high-titer replication-defective recombinant adenovirus vectors (23). As such, we constructed adenovirus vectors encoding either human or mouse CD154. Because soluble, recombinant mouse CD154 had been found to bind human CD40 (24), the rationale underlying construction of the latter was to generate a vector encoding a functional heterologous ligand for human CD40 that could be distinguished from endogenously expressed human CD154 on infected human cells. We examined whether infection of CLL cells with either vector could induce changes in the leukemia B cell phenotype that could facilitate $\mathrm{T}$ cell immune recognition. 


\section{Methods}

Cells. After informed consent, blood was obtained from patients satisfying diagnostic criteria for B cell CLL $(1,2)$. Approximately $97 \%$ of the mononuclear cells isolated via Histopaque 1077 (Sigma Chemical Co., St. Louis, MO) coexpressed CD19 and CD5, as assessed by flow cytometry. CLL B cells were frozen in FCS containing $10 \%$ DMSO (Sigma Chemical Co.) and stored in liquid nitrogen before use. Autologous T cells were isolated from the PBMC of CLL patients using anti-CD4- and anti-CD8-conjugated magnetic beads (Dynal, Lake Success, NY). After incubation with PBMC $\left(5 \times 10^{7}\right)$ and magnetic beads $(200 \mu \mathrm{l} / \mathrm{each})$ for $1 \mathrm{~h}$ at $4^{\circ} \mathrm{C}$, magnetic beadbound $\mathrm{CD}^{+}$and $\mathrm{CD} 8^{+} \mathrm{T}$ cells were eluted by DETACHaBEAD $(200 \mu \mathrm{l})$ according to the manufacturer's instructions. The purified cells $\left(\sim 3 \times 10^{6}\right)$ were analyzed by flow cytometry and found to be lymphocytes, of which $>95 \%$ expressed CD3.

Allogeneic T cells were purified from PBMC of normal healthy donors via density gradient centrifugation in Histopaque 1077 (Sigma Chemical Co.). Monocytes and B cells were depleted by adherence to anti-CD14- and anti-CD19-conjugated magnetic beads (Dynal). Magnetic depletion of bead-bound cells resulted in $>95 \%$ pure $\mathrm{CD}^{+} \mathrm{T}$ cells, as determined by flow cytometry.

HeLa cells were obtained from the American Type Culture Collection (Bethesda, MD) and cultured in RPMI 1640, supplemented with $10 \%$ fetal calf sera. To harvest cultured cells we removed the culture media and added $10 \mathrm{mM}$ EDTA in PBS ( $\mathrm{pH}$ 7.2) for $5 \mathrm{~min}$ at $37^{\circ} \mathrm{C}$. The cells were harvested and then washed in media.

Adenovirus vectors. The adenovirus vector encoding $\beta$-gal, AdlacZ, was as described (23). To generate the adenovirus vector encoding human CD154, we obtained the cDNA encoding human CD154 (25) from Dr. Melanie K. Spriggs (Immunex, Seattle, WA). To generate the adenovirus vector encoding the murine CD154, we isolated total RNA using the RNA STAT-60 kit (Tel-Test "B" Inc., Friendswood, TX) from $10^{7} \mathrm{~B} 6$ mouse splenocytes that were previously activated for $8 \mathrm{~h}$ with immobilized CD3-specific mAb. The cDNA were synthesized with the Superscript cDNA synthesis kit (GIBCO BRL, Gaithersburg, MD) using oligo-dT primers. The murine CD154 gene was amplified from the cDNA by PCR using the sense primer 5'-GTTAAGCTTTTCAGTCAGTCAGCATGATAGAA-3' (nt 2-21) and antisense primer $5^{\prime}$-GTTTCTAGATCAGAGTTTGAGTAAGCC$3^{\prime}$ (nt 795-778). The cDNA encoding either human or mouse CD154 was subcloned into the multiple cloning sites of an eukaryotic expression vector $\mathrm{pRc} / \mathrm{CMV}$ (Invitrogen, San Diego, CA). A DNA fragment encompassing the CMV promoter, either human or mouse $\mathrm{CD} 154$, and a polyadenylation signal was released from this plasmid construct after restriction digestion with BgIII and XhoI enzymes. Each of these DNA fragments was subcloned into the shuttle plasmid MCS(SK)pXCX2 (23), designated human or mouse CD154 pXCX2. The human or mouse CD154 pXCX2 plasmid was cotransfected with pJM17 into 293 cells (American Type Culture Collection) using the calcium phosphate method. Isolated adenovirus plaques were picked and expanded by reinfecting 293 cells. High titer adenovirus preparations were obtained, as described (23). The virus titer was determined by infecting 293 cells with serial dilutions of the purified adenovirus and counting the number of plaques formed. Viral titers typically ranged from $10^{10}$ to $10^{12}$ plaque forming units per milliliter.

HeLa cells or $10^{6}$ freshly thawed and washed CLL B cells were suspended in $1 \mathrm{ml}$ of culture medium at $37^{\circ} \mathrm{C}$ and infected with adenovirus vectors at various moi ratios $(1-1,000)$. Adenovirus vectors encoding human CD154, murine CD154, or lacZ, designated AdhCD154, Ad-CD154, or Ad-lacZ respectively, were added to the CLL cells at an moi of 1,000 , as described (23).

Flow cytometry. The cells were washed and then suspended in staining media, consisting of RPMI $1640,3 \% \mathrm{FCS}, 0.05 \% \mathrm{NaN}_{3}$, and $1 \mu \mathrm{g} / \mathrm{ml}$ propidium iodide (PI) with saturating amounts of fluorochrome-conjugated mAbs specific for human or mouse CD154 (PharMingen, San Diego, CA). After $30 \mathrm{~min}$ at $4^{\circ} \mathrm{C}$, the cells were washed with staining media and analyzed via flow cytometry using a
FACS-Calibur ${ }^{\circledR}$ (Becton Dickinson, San Jose, CA). Dead cells staining with PI were excluded from the analyses. The relative expression of surface antigen is described as the mean fluorescence intensity ratio (MFIR). MFIR equals the MFI of cells stained with a fluorochrome-conjugated antigen-specific mAb divided by the MFI of cells stained with a fluorochrome-conjugated isotype control $\mathrm{mAb}$.

Fluorescein-conjugated mAbs specific for human CD54 or CD70 were purchased from Caltag (Burlingame, CA). Fluorescein-conjugated mAb specific for human CD27, CD58, CD80, CD86, or CD95 and phycoerythrin (PE)-conjugated $\mathrm{mAb}$ specific for human or mouse CD154 were obtained from PharMingen. For analysis of $\beta$-gal expression, the cells were stained with the $\beta$-gal fluorescent substrate, fluorescein di- $\beta$-D-galactopyranoside (Molecular Probes, Eugene, OR), as described (23).

ELISA for soluble CD27. Soluble CD27 was measured by ELISA using two non-cross-blocking CD27 mAbs (clones M-T271 and L128 [26]) provided by Dr. Ko Okumura (Juntendo University, Tokyo, Japan). For this, polystyrene microtiter plates were coated with M-T271 at $5 \mu \mathrm{g} / \mathrm{ml}$ in $0.2 \mathrm{M}$ phosphate buffer ( $\mathrm{pH} 9.0$ ). The plates were washed with PBS and treated for $2 \mathrm{~h}$ at room temperature with blocking buffer ( $1 \%$ BSA and $0.01 \%$ sodium azide in PBS). The plates were washed four times with wash buffer (0.05\% Tween 20 in PBS) and incubated for $1 \mathrm{~h}$ at room temperature with culture supernatants diluted in blocking buffer. As a standard, we used a CD27-Ig fusion protein (27), provided by Dr. Raymond Goodwin (Immunex Corp.). The plates were washed four times with wash buffer and incubated for $1 \mathrm{~h}$ with biotinylated L128 mAb at $5 \mu \mathrm{g} / \mathrm{ml}$ in blocking buffer. Washed plates then were treated sequentially with Avidin and then biotinylated horseradish peroxidase (Elite Vectastain ${ }^{\mathrm{TM}}$; Vector Laboratories, Burlingame, CA), that then was allowed to react with its substrate TMB peroxidase (Kirkegaard \& Perry Laboratories, Gaithersburg, MD). The OD at $450 \mathrm{~nm}$ was determined using an ELISA microplate reader (Molecular Devices, Menlo Park, CA).

Trans-activation assay. CD154-CLL or CLL B cells were prelabeled with a green fluorescence dye (CellTracker ${ }^{\mathrm{TM}}$ Green CMFDA; Molecular Probes) at a concentration of $40 \mu \mathrm{M}$ for $15 \mathrm{~min}$ at $37^{\circ} \mathrm{C}$. After washing, the green fluorescence-labeled CD154-CLL B cells, or the green fluorescence-labeled control CLL B cells, were cocultured with noninfected, nonstained CLL B cells at $37^{\circ} \mathrm{C}$. After $2 \mathrm{~d}$, expression of CD54 and CD86 on noninfected, green fluorescencenegative CLL B cells was analyzed by PE-conjugated anti-CD54 and anti-CD86 mAbs (PharMingen).

Mixed lymphocyte reactions (MLTR). Allogeneic MLTR were performed using a protocol modified from one described previously (9-11). Adenovirus vectors encoding murine CD154 or lacZ, designated Ad-CD154 or Ad-lacZ, respectively, were added to the CLL cells at an moi of 1,000. CLL B cells were cultured for $3 \mathrm{~d}$ at $10^{6} \mathrm{cells} / \mathrm{ml}$ in serum-free AIM-V culture medium (GIBCO BRL), supplemented with human IL-4 (R\&D Systems, Minneapolis, MN) at $10 \mathrm{ng} / \mathrm{ml}$. Alternatively, CLL cells were stimulated with G28-5 mAb (28) (provided by Dr. Edward Clark, University of Washington, Seattle, WA), or an isotype control $\mathrm{mAb}$, MOPC21, presented by murine CD32-L cells in AIM-V media supplemented with $10 \mathrm{ng} / \mathrm{ml}$ of IL-4, as described $(9,29)$.

After 3 d, adenovirus-infected or anti-CD40-stimulated CLL B cells were harvested and treated with mitomycin C (Sigma Chemical Co.) at a concentration of $60 \mu \mathrm{g} / \mathrm{ml}$ for $1 \mathrm{~h}$ at $37^{\circ} \mathrm{C}$ to inhibit proliferation. These cells then were washed three times and plated into a 96well U-bottom culture plate (Corning, Cambridge, MA) at $5 \times 10^{4}$ cells/well for use as stimulator cells. Purified normal T cells in AIM-V medium were added at $2 \times 10^{5}$ cells/well in a final total volume of $200 \mu \mathrm{l}$, and plates were incubated at $37^{\circ} \mathrm{C}, 5 \% \mathrm{CO}_{2}$. After $2 \mathrm{~d}$, cell-free supernatants were collected and tested for human IFN- $\gamma$ by ELISA using two mAbs obtained from PharMingen, according to the manufacturer's instructions. Serial dilutions of recombinant human IFN- $\gamma$ (Sigma Chemical Co.) was used as the standard. After $5 \mathrm{~d}$, the proliferative response was measured by supplementing the cultures with $0.5 \mu \mathrm{Ci} /$ well $\left[{ }^{3} \mathrm{H}\right]$ thymidine (DuPont/NEN, Boston, MA) for $8 \mathrm{~h}$ be- 
fore harvesting the cells onto glass fiber filters. Filter-bound $\left[{ }^{3} \mathrm{H}\right]$ thymidine incorporated into newly synthesized DNA was measured using a scintillation counter (Beckman Instruments, Fullerton, CA)

For the autologous MLTR, T lymphocytes were isolated from the blood mononuclear cells of patients with CLL to $>95 \%$ purity, as described. Purified T cells $\left(2 \times 10^{5}\right)$ were cocultured with various stimulators $\left(5 \times 10^{4}\right)$ in AIM-V serum-free medium supplemented with recombinant human IL-2 (Sigma Chemical Co.) at $25 \mathrm{U} / \mathrm{ml}$ for various time periods. IFN- $\gamma$ concentration was assessed in supernatants after $48 \mathrm{~h}$ of culture, and $\left[{ }^{3} \mathrm{H}\right]$ thymidine incorporation was measured for the last $8 \mathrm{~h}$ of a 5-d culture. $5 \mathrm{~d}$ after autologous MLTR, T cells were isolated over Histopaque and further cultured for $1 \mathrm{~d}$ in AIM-V medium without exogenous IL-2 for use as effector cells in the cytotoxic T lymphocyte (CTL) assay.

CTL assay. Cytolytic activity against CLL B cells was determined by the modified annexin $\mathrm{V}$ assay $(30,31)$. T cells from autologous MLTR $\left(10^{5}\right)$ were cocultured in AIM-V medium with freshly thawed and noninfected CLL B cells $\left(5 \times 10^{4}\right)$ in 96-well U-bottom plates for $3 \mathrm{~h}$ at $37^{\circ} \mathrm{C}$. Cells were stained with PE-conjugated CD19 followed by staining with FITC-labeled annexin V (PharMingen) plus PI and analyzed by flow cytometry. Apoptotic target CLL B cells gated on PE-CD $19^{+}$appeared in the $\mathrm{FL}-1^{+}$region, and the percentage of cytolysis was calculated from the following formula: \% cytolysis $=100 \times$ number of FL-1-positive target cells/number of total target cells gated on $\mathrm{CD}_{19^{+}}$cells. In some experiments, mAbs were added to effector and target cells upon initiation of the assay to a final concen-

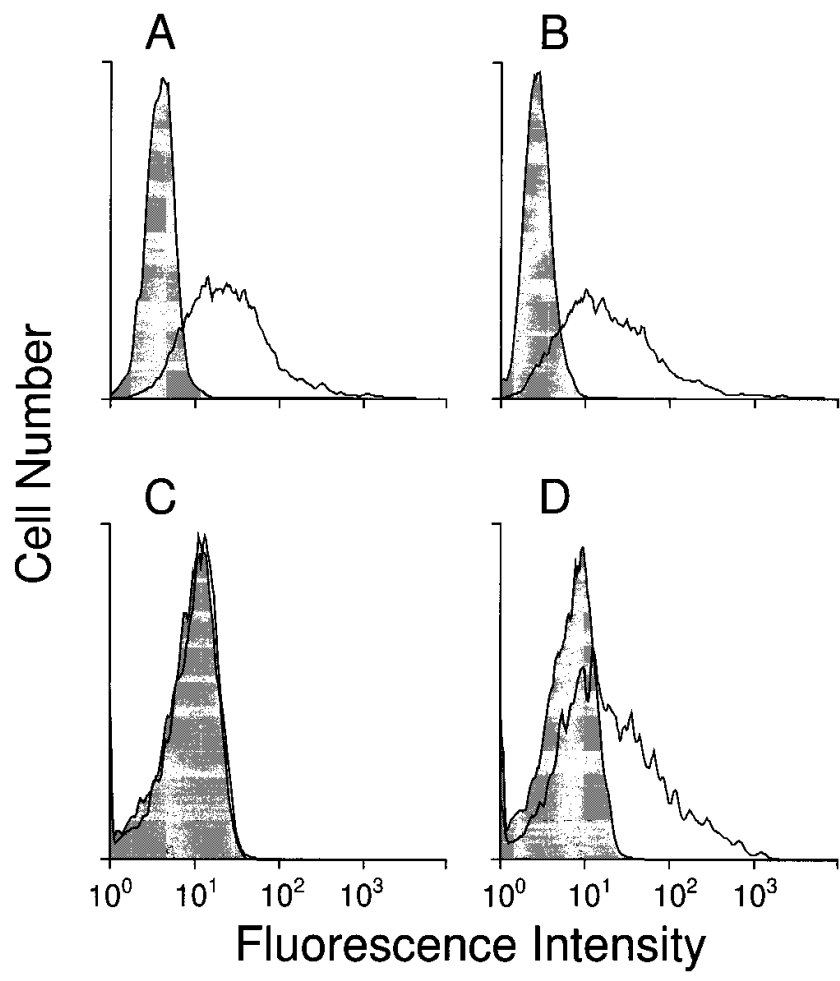

Figure 1. Infection of HeLa cells ( $A$ and $B)$ or CLL cells $(C$ and $D)$ with adenovirus vectors encoding CD154. HeLa cells were infected at an moi of 10 , whereas CLL cells were infected at an moi of 1,000 , with adenovirus vectors encoding human $(A$ and $C)$ or mouse $(B$ and $D)$ CD154. The cells were analyzed for expression of CD154 by flow cytometry $2 \mathrm{~d}$ after infection. Shaded histograms represent the fluorescence of cells stained with a FITC-conjugated isotype control mAb. Open histograms represent the fluorescence of cells stained with FITC-conjugated $\mathrm{mAb}$ specific for human $(A$ and $C)$ or mouse $(B$ and $D)$ CD154. tration of $3 \mu \mathrm{g} / \mathrm{ml}$. These included the anti-HLA class I mAb, W6/32 (32), the polymorphic anti-HLA-DP mAb, B7/21 (33) (Becton Dickinson), the anti-Fas-ligand mAb, NOK3 (34) from Dr. Ko Okumura, or an isotype control Ig of irrelevant specificity, MOPC21 (PharMingen).

\section{Results}

Expression of native or heterologous CD154 in CLL B cells. We generated adenovirus vectors encoding either human or mouse CD154. HeLa cells infected with either adenovirus vector expressed high levels of human or mouse CD154, as assessed by flow cytometry (Fig. 1, $A$ and $B$ ). However, infection of CLL B cells with the adenovirus encoding human CD154 (designated Ad-hCD154) did not result in detectable surface expression of CD154, even at high moi ratios (e.g., $>10^{4}$ ) (Fig. $1 C$ ). On the other hand, the adenovirus vector encoding the mouse CD154 (designated Ad-CD154) could effect stable, high-level surface expression of a ligand for CD40 on infected leukemia cells (Fig. $1 \mathrm{D}$ ). Moreover, surface expression reached a peak level at $48 \mathrm{~h}$ after infection and persisted at high levels for at least $6 \mathrm{~d}$ thereafter (Fig. 2).

Induction of immune accessory molecules on infected CLL $B$ cells. Adenovirus-infected CLL cells from each of seven different patients were evaluated for induced expression of various immune accessory molecules important in cognate $\mathrm{B}$ cell-T cell interactions. In contrast to mock-infected or Ad-lacZ-infected CLL cells (Fig. 3, thin-lined histograms), CLL cells infected with Ad-CD154 (designated CD154-CLL) expressed high levels of CD54 (Fig. 3, top left), CD80 (Fig. 3, top middle), CD86 (Fig. 3, top right), CD58 (Fig. 3, bottom left), CD70 (Fig. 3, bottom middle), and CD95 (Fig. 3, bottom right). On the other hand, CD154-CLL expressed significantly lower levels of both surface membrane CD27 (Fig. $4 A$ ) and soluble CD27 (Fig. 4 B) than mock-infected or Ad-lacZ-

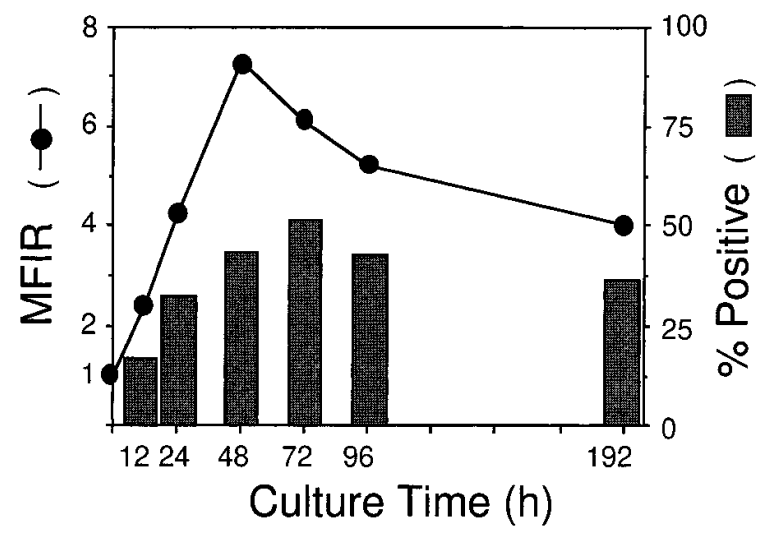

Figure 2. Time course of transgene expression in Ad-CD154infected CLL B cells. CLL B cells were infected with Ad-CD154, at an moi of 1,000 at time 0 , and then assessed by flow cytometry at various times thereafter. At each time point listed on the abscissa, the proportions of viable CLL B cells that expressed detectable CD154 are indicated by the vertical bars corresponding to the percent scale depicted on the right-hand ordinate. The MFIR, comparing the fluorescence intensity of $\mathrm{CD} 19^{+}$CLL cells stained with PE-labeled CD154 versus the same stained with a PE-labeled isotype control $\mathrm{mAb}$ at each time point, are represented by the closed circles connected by solid lines according to the scale provided on the left-hand ordinate. 


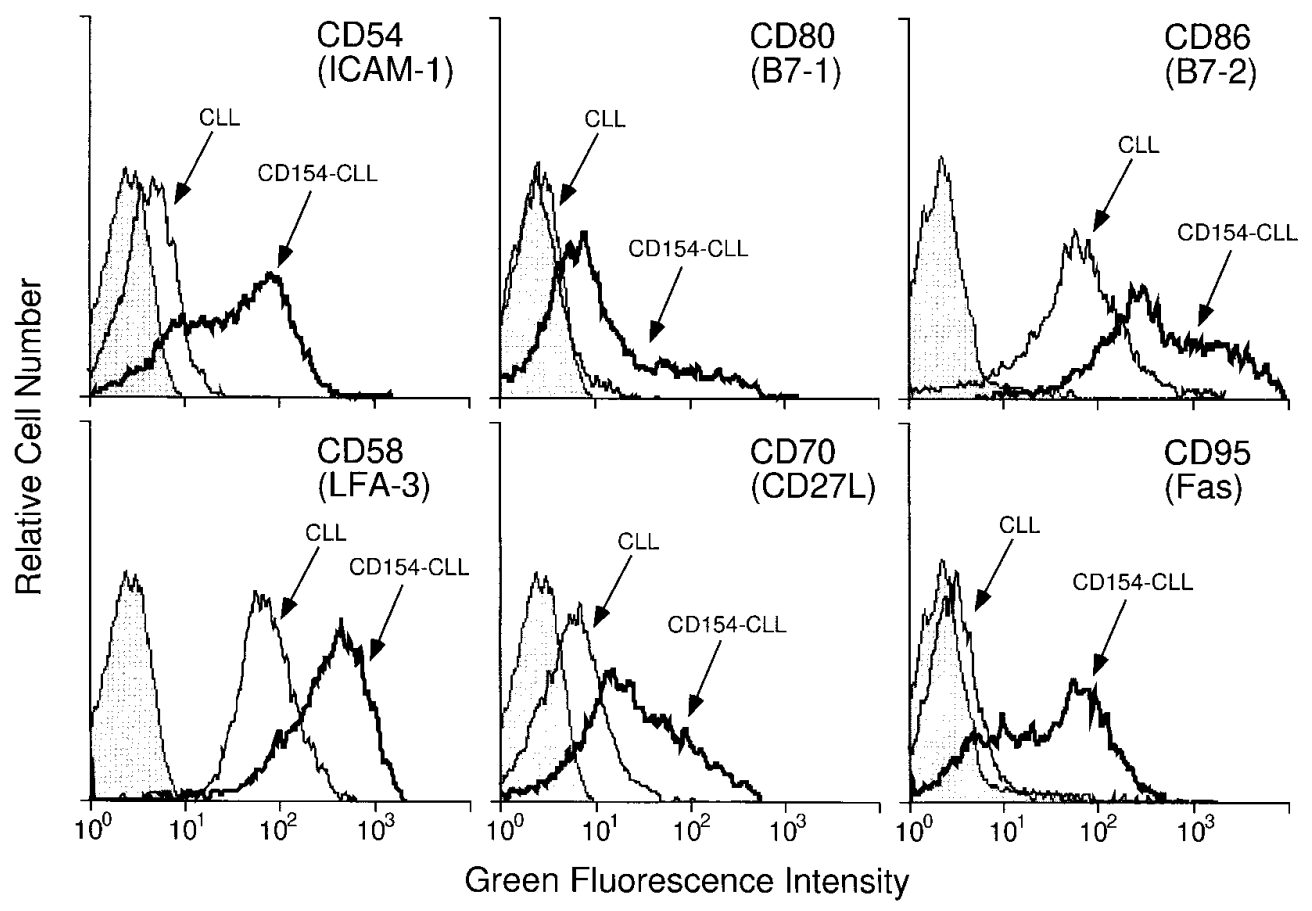

Figure 3. Changes in surface antigen phenotype of CLL B cells infected with Ad-CD154 (CD154-CLL). $3 \mathrm{~d}$ after infection, the CLL B cells were examined for surface expression of CD54 (ICAM-1), CD80 (B7-1), CD86 (B7-2), CD58 (LFA-3), CD70 (CD27-ligand), and CD95 (Fas) by flow cytometry. Shaded histograms represent staining of CLL B cells with FITC-conjugated isotype control $\mathrm{mAb}$. Open histograms represent staining of noninfected CLL cells (thin lines) or CD154-CLL (thick lines) with FITC-conjugated specific $\mathrm{mAb}$, respectively. infected CLL cells $(P<0.01$, Bonferroni $t$ test $)$. These results were consistent for the leukemia cells of each of seven patients studied. The reduced expression of CD27 is similar to that noted for leukemia B cells stimulated via CD40 cross-linking with mAb G28-5 presented by CD32-expressing L cells (Fig. 4 B) (10).

Trans-activation of noninfected bystander leukemia B cells. To address whether these phenotypic changes resulted from intracellular versus intercellular stimulation, we examined the effect of culture density on the induced expression of CD54 and CD80 after infection with Ad-CD154. After infection, CLL cells were cultured at standard high density (e.g., $10^{6}$ cells $/ \mathrm{ml}$ ) or low density (e.g., $2 \times 10^{5}$ cells $/ \mathrm{ml}$ ) for $3 \mathrm{~d}$ at $37^{\circ} \mathrm{C}$. Cells plated at high density contained homotypic aggregates, whereas cells plated at low density remained evenly dispersed and without substantial cell-cell contact (data not shown). Despite expressing similar levels of heterologous CD154, CD154CLL B cells cultured at high density were induced to express higher levels of CD54 and CD80 than CD154-CLL cells cultured at low density (Fig. $5 \mathrm{~A}$ ). The stimulation achieved at high density could be inhibited by culturing the cells with a hamster anti-mouse CD154 mAb capable of blocking CD40 CD154 interactions (Fig. $5 \mathrm{~B}, \alpha C D 154 \mathrm{Ab}$ ). Collectively, these studies indicate that CD154-CLL cells can activate each other in trans and that surface expression of CD154 is necessary for optimal leukemia cell stimulation.

We labeled Ad-CD154-infected, mock-infected, Ad-lacZinfected, or G28-5-stimulated CLL cells with a green fluorescence dye to examine whether CD154-CLL could stimulate noninfected bystander leukemia cells. Dye-labeled cells were used as stimulator cells for equal numbers of nonlabeled syngeneic CLL B cells. After $2 \mathrm{~d}$ of culture, stimulator cells cultured by themselves retained the green fluorescence dye, allowing such cells to be distinguished from nonlabeled CLL cells by flow cytometry. We found that bystander (green fluorescence-negative) $\mathrm{CD} 19^{+}$CLL B cells were induced to ex-
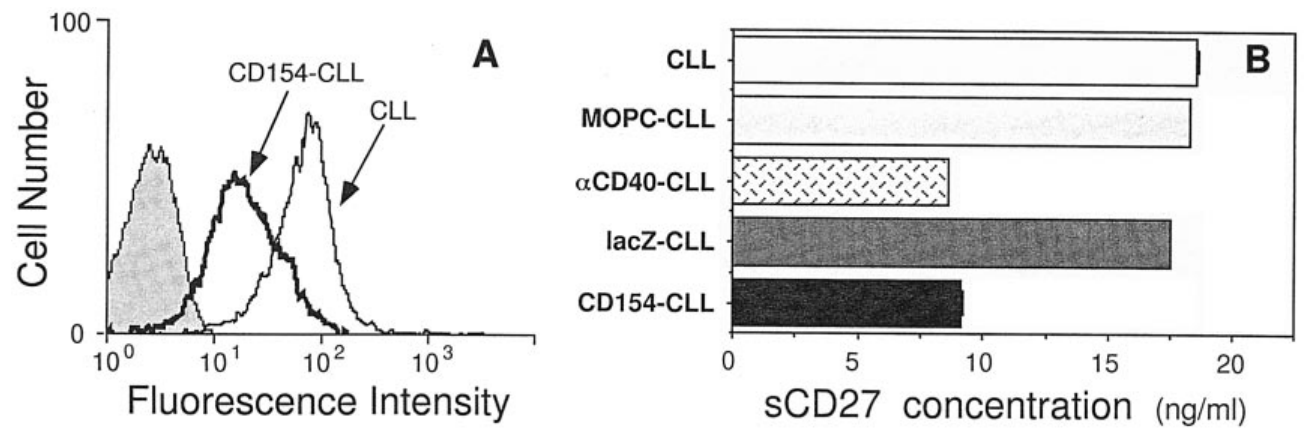

Figure 4. (A) CD154-CLL express reduced levels of surface CD27. $3 \mathrm{~d}$ after infection, the CLL B cells were examined for expression of CD27 via flow cytometry. Shaded histograms represent staining of CLL B cells with FITC-conjugated isotype control mAb. Open histograms represent staining of noninfected CLL cells (thin lines) or CD154CLL (thick lines) with FITCconjugated $\alpha \mathrm{CD} 27 \mathrm{mAb}$, respectively. (B) Production of soluble form of CD27 by CLL B cells. Cell-free supernatants were collected after the infection or stimulation of CLL B cells for $72 \mathrm{~h}$ and tested for the concentration of human CD27 by ELISA. Data represent the mean \pm SE of triplicate wells. 
A
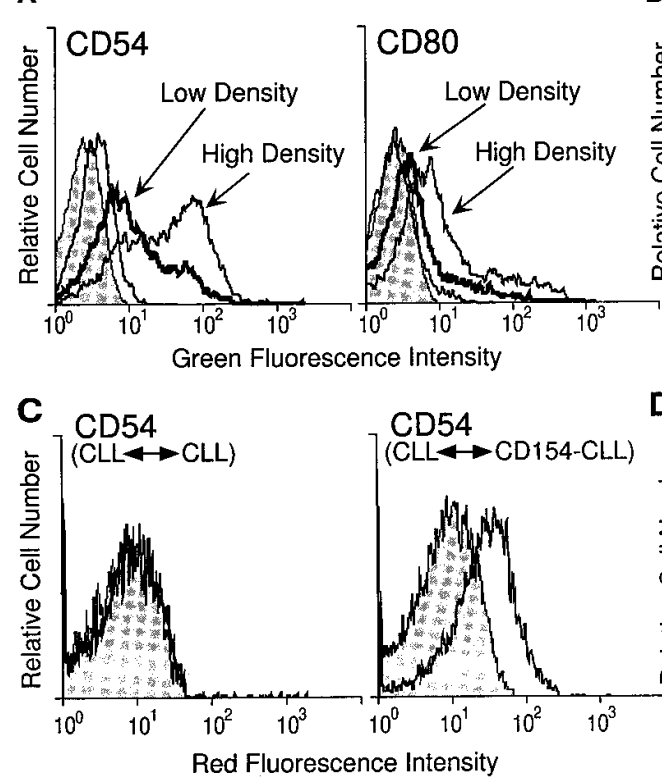

B

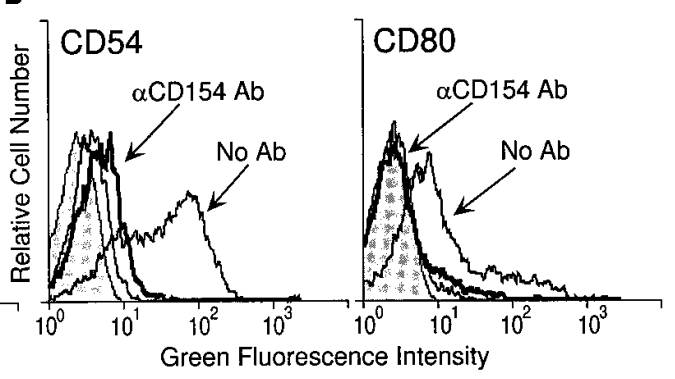

D

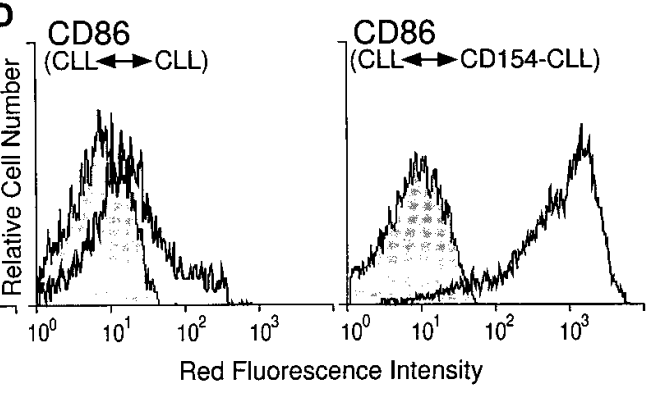

Figure 5. (A) Induction of surface antigen on CD154-CLL $B$ cells at different cell densities. CLL B cells were infected with Ad-CD154 and cultured at low cell density $\left(2 \times 10^{5}\right.$ cells $\left./ \mathrm{ml}\right)$ or high cell density $\left(10^{6}\right.$ cells $\left./ \mathrm{ml}\right)$, respectively. Expression of CD54 (left) or CD80 (right) was assessed by flow cytometry. Shaded histograms represent staining of leukemia B cells with a FITC-conjugated isotype control mAb. Open histograms represent CD154-CLL B cells cultured at high or low density (arrows) that were stained with a FITC-conjugated mAbs specific for CD54 or CD80. (B) Inhibition of CD154-CLL cell activation by anti-CD $154 \mathrm{mAb}$. CLL B cells were infected with Ad$\mathrm{CD} 154$ in the presence $(\alpha C D 154$ $m A b$ ) or absence (No $A b$ ) of hamster anti-mouse CD154

$\mathrm{mAb}$. After $3 \mathrm{~d}$ of culture, the expression of CD54 or CD80 was assessed by flow cytometry. $(C$ and $D)$ Expression of immune accessory molecules on bystander noninfected CLL B cells induced by CD154-CLL. Noninfected CLL B cells were cocultured with green fluorescence-labeled noninfected CLL cells (left histograms) or green fluorescence-labeled CD154-CLL cells (right histograms) at $37^{\circ} \mathrm{C}$. After $2 \mathrm{~d}$, the level of CD54 or CD86 expressed by green fluorescence-negative bystander CLL B cells was determined by staining with PE-conjugated mAb specific for CD54 $(C)$ or anti-CD86 $(D)$. Shaded histograms represent staining with PE-conjugated isotype control mAb.

press CD54 (Fig. 5 C, right histogram) or CD86 (Fig. 5 D, right histogram) when cocultured with Ad-CD154-infected leukemia B cells, but not with mock-infected CLL cells (Fig. 5, C and D, left histograms), G28-5-stimulated CLL cells, or AdlacZ-infected CLL cells (data not shown). As expected, these bystander (green fluorescence-negative) CLL cells also were negative for heterologous CD154.

Allogeneic mixed T cell reactions. We evaluated whether Ad-CD154-infected, Ad-lacZ-infected, or mock-infected leukemia B cells could act as stimulator cells in an allogeneic MLTR. In parallel, we also examined the stimulatory capacity of leukemia B cells that had been cultured with CD32-L cells and an anti-CD40 mAb (G28-5) or an isotype control Ig, as described $(9,28,35)$. Effector $\mathrm{T}$ cells from a nonrelated donor were cocultured with mitomycin $\mathrm{C}$-treated leukemia stimulator cells at an effector to target ratio of $4: 1$. After $18 \mathrm{~h}$ of culture at $37^{\circ} \mathrm{C},>30 \%$ of the allogeneic $\mathrm{CD}^{+}$cells were found to express the activation-associated antigen CD69 when cultured with CD154-CLL cells (data not shown). In contrast, $<4 \%$ of the $\mathrm{T}$ cells expressed CD69 when cocultured with mock-infected or Ad-lacZ-infected CLL cells (data not shown).

$2 \mathrm{~d}$ after the initiation of the MLTR, we assessed the concentrations of IFN- $\gamma$ in the culture supernatants by ELISA. The supernatants of the MLTR stimulated with CD154-CLL cells (Fig. $6 A, C D 154-C L L$ ) contained significantly higher levels of IFN- $\gamma(306 \pm 5 \mathrm{ng} / \mathrm{ml}$, mean $\pm \mathrm{SE}, n=3)$ than that of MLTR cultures stimulated with the anti-CD40 mAb (Fig. $6 \mathrm{~A}$, $\alpha C D 40-C L L)(23 \pm 3 \mathrm{ng} / \mathrm{ml})(P<0.05$, Bonferroni $t$ test $)$. The latter was not significantly different from that of MLTR cultures stimulated with Ad-lacZ-infected CLL cells (Fig. $6 \mathrm{~A}$, lac Z-CLL) $(43 \pm 10 \mathrm{ng} / \mathrm{ml})(P>0.1$, Bonferroni $t$ test $)$. The su- pernatants of effector cells alone, or of MLTR cultures stimulated with mock-infected CLL cells (Fig. $6 A, C L L$ ) or control Ig-treated CLL cells (Fig. 6 A, MOPC-CLL), did not contain detectable amounts of IFN- $\gamma(<2 \mathrm{ng} / \mathrm{ml})$. Similarly, none of the leukemia $\mathrm{B}$ cell populations produced detectable amounts of IFN- $\gamma$ when cultured alone, without added effector T cells (data not shown).

After $5 \mathrm{~d}$, cell proliferation was assessed by incorporation of $\left[{ }^{3} \mathrm{H}\right]$ thymidine. Cultures with isotype control IgG-treated (Fig. $6 \mathrm{~B}, M O P C$-CLL) or mock-infected (Fig. $6 \mathrm{~B}, C L L$ ) stimulator cells did not incorporate more $\left[{ }^{3} \mathrm{H}\right]$ thymidine than cultures without added leukemia-stimulator cells (Fig. $6 \mathrm{~B}$, None). Ad-lacZ-infected CLL B cells (Fig. 6 B, lacZ-CLL) also were unable to stimulate allogeneic $\mathrm{T}$ cells to incorporate amounts of $\left[{ }^{3} \mathrm{H}\right]$ thymidine that were much greater than that of control cultures. In contrast, anti-CD40-stimulated leukemia cells or CD154-CLL cells each induced significant effector cell proliferation (Fig. $6 \mathrm{~B}, \alpha C D 40-C L L$ or CD154-CLL) $(P<$ 0.05 , Bonferroni $t$ test). Moreover, the amount of $\left[{ }^{3} \mathrm{H}\right]$ thymidine incorporated by cultures stimulated with CD154-CLL cells $(41,004 \pm 761 \mathrm{cpm}$, mean $\pm \mathrm{SE}, n=3)$ was significantly greater than that of cultures stimulated with equal amounts of $\alpha$ CD40-CLL cells $(22,935 \pm 1,892 \mathrm{cpm}, n=3)(P<0.05$, Bonferroni $t$ test). However, neither of these mitomycin C-treated leukemia cell populations incorporated $\left[{ }^{3} \mathrm{H}\right]$ thymidine when cultured without effector T cells (data not shown). Also, as described for the MLTR between allogeneic T cells and CD40stimulated CLL cells (9-11), allogeneic T cell proliferation in response to CD154-CLL could be inhibited by CTLA-4-Ig or $\mathrm{CD} 11 \mathrm{a} \mathrm{mAb}$ when added at the initiation of the MLTR, indicating that respective interactions between CD80/CD86 and 

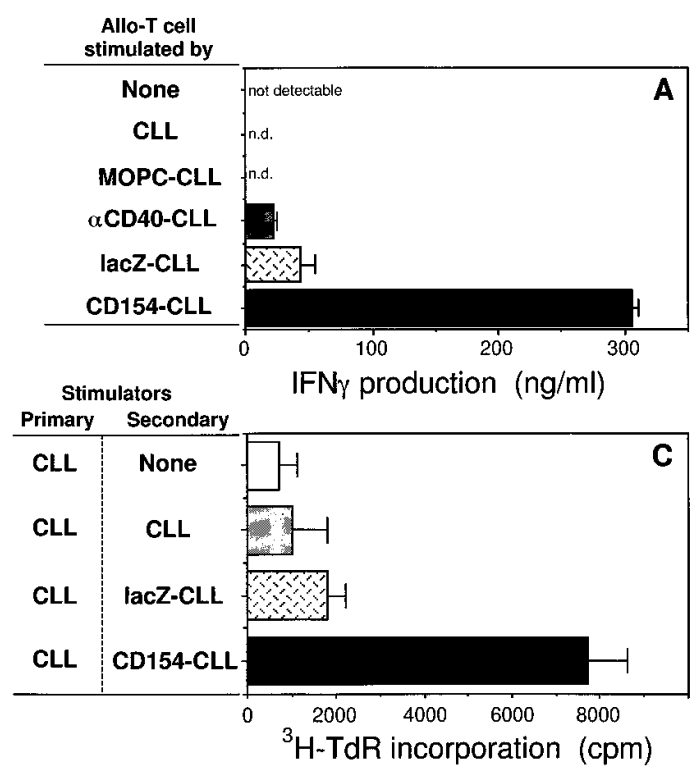
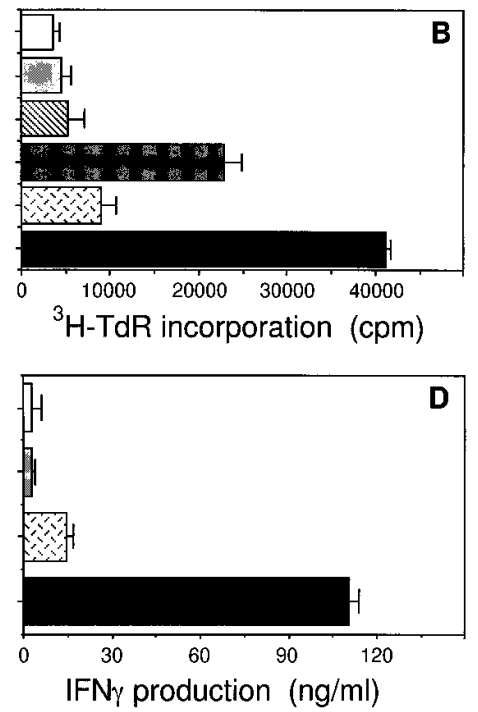

Figure 6. Allogeneic T cell responses induced by CD154-CLL. $(A)$ The concentration of IFN- $\gamma$ in the supernatants after $48 \mathrm{~h}$ of culture is indicated on abscissa. Horizontal bars represent the mean concentration of triplicate wells and the error bars depict the standard error about the mean. (B) $2 \times$ $10^{5}$ allogeneic T cells were cultured in a 96well microtiter plate with $5 \times 10^{4}$ mitomycin C-treated stimulator CLL B cells, as described. Wells were supplemented with $0.5 \mu \mathrm{Ci}$ of $\left[{ }^{3} \mathrm{H}\right]$ thymidine for the final $8 \mathrm{~h}$ of a 5-d culture. Counts per minute ( $\mathrm{cpm}$ ) of incorporated $\left[{ }^{3} \mathrm{H}\right]$ thymidine are presented on the abscissa. Error bars denote the standard error about the mean cpm of triplicate wells. ( $C$ and $D$ ) Secondary allogeneic $\mathrm{T}$ cell responses induced by CD154-CLL. Allogeneic T cells were cultured with mitomycin C-treated CLL B cells (noninfected) at a 4:1 (responder/stimulator) ratio. After $4 \mathrm{~d}$ of primary culture, $\mathrm{T}$ cells were isolated via Ficoll density-gradient separation,

washed extensively, and then cultured in media for $24 \mathrm{~h}$. Primary stimulated $\mathrm{T}$ cells were restimulated with various secondary stimulators, as described. $\left[{ }^{3} \mathrm{H}\right]$ Thymidine incorporation was measured for the last $8 \mathrm{~h}$ of a 3 -d culture $(C)$, and IFN- $\gamma$ concentration of supernatants was assessed by ELISA at $48 \mathrm{~h}$ after initiation of culture $(D)$. Data represent mean \pm SE of triplicate wells.

CD28, or CD54 and CD11a/CD18, contribute to the noted allogeneic $\mathrm{T}$ cell reaction (data not shown).

Prior studies indicated that antigen presentation to $\mathrm{T}$ cells without the signals derived from costimulatory molecules such as CD28 can lead to specific T cell clonal anergy (36-38). For this reason, we examined whether allogeneic $\mathrm{T}$ cells that had been cultured previously with nonmodified CLL B cells, lacking expression of CD80 and other immune accessory molecules, could still respond to CD154-CLL cells. Allogeneic effector cells did not incorporate more $\left[{ }^{3} \mathrm{H}\right]$ thymidine in response to nonmodified CLL cells (Fig. $6 C, C L L$ ), or CLL cells infected with Ad-lacZ (Fig. $6 C$, lacZ-CLL), than when they were cultured alone (Fig. $6 C$, None). In contrast, even after prior coculture with nonmodified CLL B cells, allogeneic effector cells could still be induced to proliferate (Fig. $6 C$, $C D 154-C L L)$ or to produce IFN- $\gamma$ (Fig. $6 D, C D 154-C L L)$ in response to CD154-CLL. Although modest amounts of IFN- $\gamma$ were detected in the supernatants of such secondary cultures when Ad-lacZ-infected leukemia cells were used as stimulator cells (Fig. 6 D, lacZ-CLL), this level was significantly lower than that noted for secondary cultures with Ad-CD154-infected CLL cells (Fig. 6 D, CD154-CLL) $(P<0.05$, Bonferroni $t$ test). Similarly, the supernatants of the leukemia cells alone (data not shown), the effector cells alone (Fig. $6 \mathrm{D}$, None), or the MLTR cultures stimulated with mock-infected CLL cells (Fig. $6 D, C L L)$ contained negligible amounts of IFN- $\gamma(<2 \mathrm{ng} / \mathrm{ml})$. Collectively, these studies indicate that allogeneic effector cells cultured with nonmodified CLL B cells are not precluded from responding to Ad-CD154-infected CLL B cells.

Autologous $T$ cell response and generation of $C T L$ by CD154-CLL. T cells isolated from the blood of CLL patients were examined for their ability to respond to autologous CD154-CLL B cells in vitro. T cells were isolated to $>95 \%$ purity, and then cocultured with mitomycin C-treated autologous leukemia cells in serum-free AIM-V medium supple- mented with exogenous IL-2, at $25 \mathrm{U} / \mathrm{ml}$. We detected modest $\left[{ }^{3} \mathrm{H}\right]$ thymidine incorporation $(\leq 10,000 \mathrm{cpm})$ in cultures without added stimulator cells, secondary in part to the exogenous IL-2 (Fig. $7 A$, and data not shown). However, the level of T cell proliferation did not increase in response to mock-infected CLL cells (Fig. $7 A, C L L$ ) or Ad-lacZ-infected CLL cells (Fig. $7 A$, lacZ-CLL). In contrast, Ad-CD154-infected CLL cells (Fig. $7 A, C D 154-C L L$ ) induced autologous T cells to incorporate significantly more $\left[{ }^{3} \mathrm{H}\right]$ thymidine $(17,368 \pm 1,093 \mathrm{cpm}, n=$ $3)$ than any of the control cultures $(P<0.05$, Bonferroni $t$ test). Furthermore, the MLTR stimulated with Ad-CD154infected CLL cells also generated significantly more IFN- $\gamma$ $(165 \pm 3 \mathrm{ng} / \mathrm{ml}, n=3)$ than any of the other cultures (Fig. $7 \mathrm{~B}$ ) $(P<0.05$, Bonferroni $t$ test $)$.

The $\mathrm{T}$ cells were harvested after $5 \mathrm{~d}$ from the autologous MLTR and assessed for CTL activity against autologous CLL B cells. T cells cocultured with autologous CD154-CLL cells developed CTL activity for nonmodified CLL B cells, effecting $40.1 \%$ lysis $( \pm 2.3 \%)$ at an effector to target ratio of 2:1 (Fig. 7 $C, C D 154-C L L)$. However, such T cells did not develop detectable CTL activity for the same target cells when cocultured with mock-infected or Ad-lacZ-infected CLL cells (Fig. 7 C).

Effector cells stimulated with autologous lacZ-CLL or CD154-CLL were evaluated for their ability to secrete IFN- $\gamma$ or manifest CTL activity against allogeneic CLL B cells. We found that $\mathrm{T}$ cells stimulated in the autologous MLTR with CD154-CLL cells, but not with lacZ-CLL cells, produced significantly more IFN- $\gamma$ in response to secondary culture with nonmodified autologous CLL B cells than with allogeneic CLL B cells (Fig. $8 A)(P<0.05$, Bonferroni $t$ test). Furthermore, T cells stimulated with CD154-CLL cells, but not with lacZ-CLL cells, were cytotoxic for autologous CLL cells, but not allogeneic CLL cells (Fig. $8 \mathrm{~B}$ ). Similar results were obtained with the autologous MLTR-activated T cells of the allogeneic donor, again demonstrating specific cytotoxicity for au- 


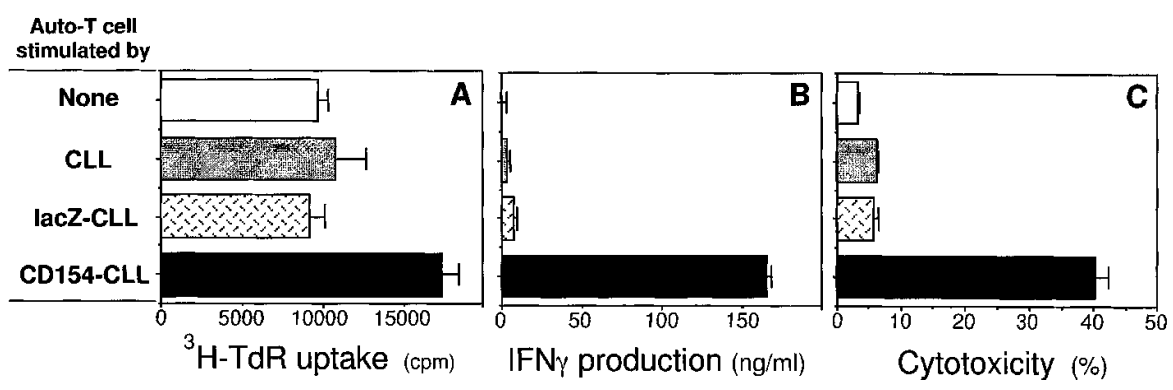

Figure 7. Autologous T cell responses induced by CD154-CLL. $(A) 2 \times 10^{5}$ autologous $\mathrm{T}$ cells purified from CLL patient were cultured with $5 \times 10^{4}$ mitomycin C-treated stimulator CLL B cells in the presence of IL-2 $(25 \mathrm{U} / \mathrm{ml})$. Wells were supplemented with $0.5 \mu \mathrm{Ci}$ of $\left[{ }^{3} \mathrm{H}\right]$ thymidine for the final $8 \mathrm{~h}$ of a 5 -d culture. The cpm of incorporated $\left[{ }^{3} \mathrm{H}\right]$ thymidine are presented on the abscissa. Error bars denote the SE of triplicate wells. (B) Cell-free supernatants were collected after $48 \mathrm{~h}$ of culture and tested for human IFN- $\gamma$ by ELISA. Data represent mean \pm SE of triplicate wells. $(C)$ After $5 \mathrm{~d}$ of autologous MLTR, the cytolytic activities of T cells were tested against autologous nonmodified CLL B cells. T cells stimulated with various stimulators were mixed with noninfected (resting) CLL B cells at a 2:1 (effector/target) ratio for $3 \mathrm{~h}$. The cells were stained with FITC-annexin V and analyzed for apoptosis by flow cytometry. The mean specific lysis \pm SE of triplicate wells was calculated as described $(30,31)$.

tologous CLL B cells (data not shown). Finally, W6/32, an $\mathrm{mAb}$ to class I MHC antigens, could significantly inhibit the cytotoxicity of $\mathrm{T}$ cells stimulated with CD154-CLL cells for autologous CLL B cells (Fig. $8 C, \alpha H L A-A B C)(P<0.05$, Bonferroni $t$ test). Such inhibition was not observed with $\mathrm{mAb}$ specific for MHC class II antigen (Fig. $8 C, \alpha H L A-D P$ ), mAb specific for the Fas-ligand (Fig. $8 C, \alpha$ Fas $L$ ), or an isotype control mAb of irrelevant specificity (Fig. 8 C, MOPC21). Collectively, these studies indicate that Ad-CD154-infected CLL cells can induce an autologous antileukemia cellular immune response in vitro, leading to the generation of MHC class I-restricted CTL specific for autologous nonmodified leukemia B cells.

\section{Discussion}

In this study, we demonstrate that infection of CLL B cells with a replication defective adenovirus vector encoding murine CD154 can cause both infected and bystander leukemia cells to become better APCs. In contrast to CLL cells infected with a control adenovirus vector, the leukemia cells infected with Ad-CD154 expressed high levels of a heterologous CD40ligand and were induced to express accessory molecules, e.g., CD80 (B7-1), that facilitate stimulatory B cell antigen presentation to $\mathrm{T}$ cells (Fig. 3). Culturing Ad-CD154-infected cells either at densities that precluded cell-cell contact or with an anti-murine CD154 mAb that precluded CD154-CD40 interactions inhibited the induced expression of such accessory molecules (Fig. 5). Moreover, addition of a murine mAb specific for human CD40 (G28-5) to cultures of Ad-CD154infected leukemia cells also could inhibit the induced expression of these accessory molecules (data not shown). Finally, Ad-CD154 infected cells could induce noninfected bystander leukemia cells also to express these costimulatory accessory molecules (Fig. 5). Collectively, these data indicate that the heterologous ligand expressed on Ad-CD154 infected cells can trans-activate infected and bystander leukemia cells via a CD40-dependent signal.

Surprisingly, infection of CLL cells with Ad-hCD154, encoding human CD154, proved to be ineffective (Fig. $1 C$ ). De-
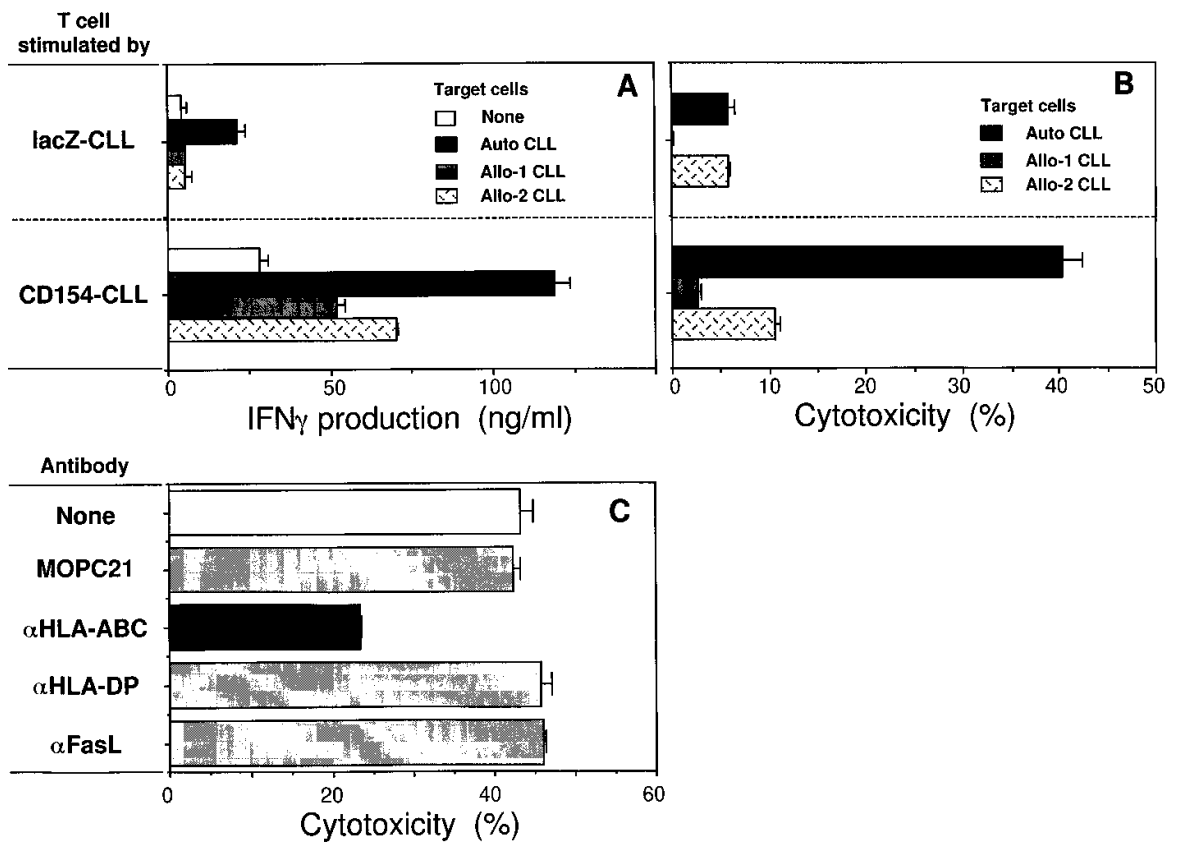

Figure 8. Specificity of CTL for autologous CLL B cells. After $5 \mathrm{~d}$ of autologous MLTR with CD154-CLL or lacZ-CLL, the $T$ cells were isolated by Ficoll density gradient centrifugation, washed extensively, and then cultured in media for $24 \mathrm{~h}$. Washed T cells were mixed with autologous (Auto CLL, solid bars) or allogeneic (Allo-1 CLL or Allo-2 CLL, hatched or shaded bars) target CLL B cells. IFN- $\gamma$ concentration was assessed in the supernatants after $48 \mathrm{~h}$ of culture $(A)$, and cytolytic activity was assessed at $3 \mathrm{~h}$ of culture $(B)$. In $C, \mathrm{mAb}$ were added to the autologous leukemia target cells before the CTL assay. The antibody added is indicated in the column to the left of the bars. In each figure, the length of the bar indicates the mean value. The error bars represent the SE of triplicate samples. 
spite finding that infection of HeLa cells with Ad-hCD154 resulted in high level surface membrane expression of this ligand (Fig. $1 \mathrm{~A}$ ), and that CLL cells infected with Ad-hCD154 expressed high levels of CD154 mRNA, as assessed by a quantitative RT-PCR assay (12) (data not shown), we could not detect expression of CD154 protein on the leukemia cell surface. Moreover, we also could not detect any induced expression of accessory molecules, such as CD80 (B7-1) or CD54, on leukemia cells infected with Ad-hCD154 (data not shown). Ordinarily, CD154 is expressed transiently on the surface of activated human $\mathrm{T}$ cells and is highly susceptible to CD40-induced downmodulation (12,17-19). As such, the CD40 expressed by the leukemia cells may preclude detection of CD154 on the leukemia cell surface or induce rapid intracellular ligand receptor downmodulation. However, the failure to detect expression of human CD154 on CLL cells cannot be due to a simple masking effect with membrane or soluble CD40, as murine CD154 also can bind human CD40 and yet can be stably expressed on the human leukemia cell surface. Conceivably, there may exist other posttranslational processing steps or metabolic pathways that also preclude expression of functional native CD154 on the leukemia B cell surface. In any case, the mouse CD154 does not seem affected, allowing for the highlevel, stable surface expression of a molecule capable of crosslinking the CD40 expressed by leukemia B cells. As such, the heterologous transgene has a distinct advantage over its human counterpart in modifying human leukemia cells into becoming more proficient APCs.

As a consequence, Ad-CD154-infected leukemia cells are highly effective stimulators of allogeneic or autologous T cells. Ad-CD154 infected leukemia cells induced significantly higher rates of allogeneic or autologous $\mathrm{T}$ cell proliferation and production of IFN- $\gamma$ than nonmodified leukemia cells or leukemia cells infected with a control adenovirus vector (Figs. 6 and 7). Importantly, Ad-CD154-infected cells also induced generation of autologous CTL capable of mediating specific lysis of autologous nonmodified leukemia cells in vitro (Figs. $7 C$ and 8). As such, CLL B cells that express murine CD154 appear capable of inducing a host antileukemia immune response that may be therapeutic. On the other hand, the use of mouse CD154 may induce an immune response in vivo that could have a negative impact on the outcome of a clinical trial testing the response to CD154-CLL cells in patients with CLL.

Prior studies demonstrated the potential for immunotherapy using tumor cells that were genetically engineered to express stimulatory cytokines or immune costimulatory accessory molecules, such as CD80 (39-41). However, the use of Ad-CD154-infected leukemia cells has several potential advantages over these approaches. First, infection of CLL cells with Ad-CD154 induces expression of a stable ligand for CD40, that in turn stimulates expression of more than just a single immune costimulatory molecule on the infected leukemia cell surface. Furthermore, leukemia cell expression of molecules that potentially can interfere with antigen presentation, such as soluble CD27, is downmodulated in CD154-CLL cells. Another important difference is that Ad-CD154-infected CLL cells can induce these phenotypic changes in bystander leukemia B cells. Such trans-stimulation may obviate having to infect large numbers of neoplastic B cells to generate the numbers of modified leukemia cells necessary for inducing an effective host antileukemia immune response.

Nadler and colleagues demonstrated that the neoplastic B cells of patients with acute lymphoblastic leukemia (pre-ALL) or follicular lymphoma (FL) also can induce autologous $\mathrm{T}$ cell immune recognition if they first are stimulated by anti-CD40 $\mathrm{mAb}$ or human CD154-expressing fibroblasts in vitro $(42,43)$. However, Ad-CD154-infected leukemia cells induce higher rates of autologous $\mathrm{T}$ cell proliferation and INF- $\gamma$ production than CLL cells stimulated via exogenous CD40 mAb or CD40ligand. This may reflect an "adjuvant effect" of adenovirus proteins expressed by the Ad-CD154-infected CLL B cell. Alternatively, the phenotypic changes induced by Ad-CD154 infection may be more resilient than those induced via exogenous stimulation. In any case, the CD154-CLL cells may be more effective for inducing CTL from autologous $\mathrm{T}$ cells against nonmodified CLL cells, allowing us to consider this approach for the immunotherapy of patients with this disease.

\section{Acknowledgments}

We thank Drs. Charles Prussak and Mary Lou Gibson for providing us with adenovirus vectors and for their helpful discussions. We also are grateful to Drs. Hideo Yagita and Ko Okumura for providing us with $\mathrm{mAb}$ antibodies to CD154, FasL, and CD27. We thank Dr. Edward A. Clark for providing us with the anti-CD40 mAb, G28-5. We also are grateful to Dr. Melanie K. Spriggs for providing us with the human CD154 cDNA and to Dr. Raymond Goodwin for the purified CD27-Ig fusion protein used as the standard in the ELISA for soluble CD27.

This work was supported in part by National Institutes of Health grants R37-CA49870RO1 and CA66000.

\section{References}

1. Kipps, T.J. 1995. Chronic lymphocytic leukemia and related diseases. In Williams Hematology. E. Beutler, M.A. Lichtman, B.S. Coller, and T.J. Kipps, editors. McGraw-Hill, Inc., New York. 1017-1039.

2. Caligaris-Cappio, F. 1996. B-chronic lymphocytic leukemia: a malignancy of anti-self B cells. Blood. 87:2615-2620.

3. Johnson, T.A., L.Z. Rassenti, and T.J. Kipps. 1997. Ig VH1 genes expressed in B-cell chronic lymphocytic leukemia exhibit distinctive molecular features. J. Immunol. 158:235-246.

4. Rassenti, L.Z., and T.J. Kipps. 1997. Lack of allelic exclusion in B cell chronic lymphocytic leukemia. J. Exp. Med. 185:1435-1445.

5. Koduru, P.R., S.M. Lichtman, T.F. Smilari, T. Sun, J.C. Goh, L. Karp, W. Hall, S. Hashimoto, N. Chiorazzi, and J.D. Broome. 1993. Serial phenotypic, cytogenetic and molecular genetic studies in Richter's syndrome: demonstration of lymphoma development from the chronic lymphocytic leukaemia cells. Br. J. Haematol. 85:613-616.

6. Lishner, M., A. Lalkin, A. Klein, S. Yarkoni, Y. Manor, M. Fejgin, V. Leytin, M. Ravid, and A. Amiel. 1995. The BCL-1, BCL-2, and BCL-3 oncogenes are involved in chronic lymphocytic leukemia. Detection by fluorescence in situ hybridization. Cancer Genet. Cytogenet. 85:118-123.

7. Agular-Santelises, M., M.E. Rottenberg, N. Lewin, H. Mellstedt, and M. Jondal. 1996. Bcl-2, Bax and p53 expression in B-CLL in relation to in vitro survival and clinical progression. Int. J. Cancer. 69:114-119.

8. Finn, W.G., M. Thangavelu, K.K. Yelavarthi, C.L. Goolsby, M.S. Tallman, A. Traynor, and L.C. Peterson. 1996. Karyotype correlates with peripheral blood morphology and immunophenotype in chronic lymphocytic leukemia. Am. J. Clin. Pathol. 105:458-467.

9. Ranheim, E.A., and T.J. Kipps. 1993. Activated T cells induce expression of B7/BB1 on normal or leukemic B cells through a CD40-dependent signal. $J$. Exp. Med. 177:925-935.

10. Ranheim, E.A., M.J. Cantwell, and T.J. Kipps. 1995. Expression of CD27 and its ligand, CD70, on chronic lymphocytic leukemia B cells. Blood. 85: 3556-3565.

11. Ranheim, E.A., and T.J. Kipps. 1995. Tumor necrosis factor-alpha facilitates induction of CD80 (B7-1) and CD54 on human B cells by activated T cells: complex regulation by IL-4, IL-10, and CD40L. Cell. Immunol. 161:226-235.

12. Cantwell, M.J., T. Hua, J. Pappas, and T.J. Kipps. 1997. Acquired CD40-ligand deficiency in chronic lymphocytic leukemia. Nat. Med. 3:984-989.

13. Armitage, R.J., W.C. Fanslow, L. Strockbine, T.A. Sato, K.N. Clifford, B.M. Macduff, D.M. Anderson, S.D. Gimpel, T. Davis-Smith, and C.R. Maliszewski. 1992. Molecular and biological characterization of a murine ligand for CD40. Nature. 357:80-82. 
14. Noelle, R.J., M. Roy, D.M. Shepherd, I. Stamenkovic, J.A. Ledbetter, and A. Aruffo. 1992. A 39-kD protein on activated helper T cells binds CD40 and transduces the signal for cognate activation of B cells. Proc. Natl. Acad. Sci. USA. 89:6550-6554.

15. Yang, Y., and J.M. Wilson. 1996. CD40 ligand-dependent T cell activation: requirement of B7-CD28 signaling through CD40. Science. 273:1862-1864.

16. Grewal, I.S., H.G. Foellmer, K.D. Grewal, J. Xu, F. Hardardottir, J.L. Baron, C.A.J. Janeway, and R.A. Flavell. 1996. Requirement for CD40 ligand in costimulation induction, $\mathrm{T}$ cell activation, and experimental allergic encephalomyelitis. Science. 273:1864-1867.

17. Roy, M., T. Waldschmidt, A. Aruffo, J.A. Ledbetter, and R.J. Noelle. 1993. The regulation of the expression of gp39, the CD40 ligand, on normal and cloned CD4+ T cells. J. Immunol. 151:2497-2510.

18. Castle, B.E., K. Kishimoto, C. Stearns, M.L. Brown, and M.R. Kehry. 1993. Regulation of expression of the ligand for CD40 on T helper lymphocytes. J. Immunol. 151:1777-1788.

19. Hermann, P., D. Blanchard, B. de Saint-Vis, F. Fossiez, C. Gaillard, B. Vanbervliet, F. Briere, J. Banchereau, and J.P. Galizzi. 1993. Expression of a 32-kD ligand for the CD40 antigen on activated human T lymphocytes. Eur. J. Immunol. 23:961-964.

20. Banchereau, J., F. Bazan, D. Blanchard, F. Briere, J.P. Galizzi, C. van Kooten, Y.J. Liu, F. Rousset, and S. Saeland. 1994. The CD40 antigen and its ligand. Annu. Rev. Immunol. 12:881-922.

21. Clark, E.A., and J.A. Ledbetter. 1994. How B and T cells talk to each other. Nature. 367:425-428

22. Durie, F.H., T.M. Foy, S.R. Masters, J.D. Laman, and R.J. Noelle. 1994. The role of CD40 in the regulation of humoral and cell-mediated immunity. Immunol. Today. 15:406-411.

23. Cantwell, M.J., S. Sharma, T. Friedmann, and T.J. Kipps. 1996. Adenovirus vector infection of chronic lymphocytic leukemia B cells. Blood. 88: 4676-4683.

24. Lane, P., T. Brocker, S. Hubele, E. Padovan, A. Lanzavecchia, and F. McConnell. 1993. Soluble CD40 ligand can replace the normal T cell-derived CD40 ligand signal to B cells in T cell-dependent activation. J. Exp. Med. 177: $1209-1213$

25. Spriggs, M.K., R.J. Armitage, L. Strockbine, K.N. Clifford, B.M. Macduff, T.A. Sato, C.R. Maliszewski, and W.C. Fanslow. 1992. Recombinant human CD40 ligand stimulates B cell proliferation and immunoglobulin E secretion. J. Exp. Med. 176:1543-1550.

26. Bigler, R.D., Y. Bushkin, and N. Chiorazzi. 1988. S152 (CD27). A modulating disulfide-linked T cell activation antigen. J. Immunol. 141:21-28.

27. Goodwin, R.G., M.R. Alderson, C.A. Smith, R.J. Armitage, T. VandenBos, R. Jerzy, T.W. Tough, M.A. Schoenborn, T. Davis-Smith, and K. Hennen. 1993. Molecular and biological characterization of a ligand for CD27 defines a new family of cytokines with homology to tumor necrosis factor. Cell. 73:447-456.

28. Clark, E.A., and J.A. Ledbetter. 1986. Activation of human B cells mediated through two distinct cell surface differentiation antigens, Bp35 and Bp50. Proc. Natl. Acad. Sci. USA. 83:4494-4498.

29. Inaba, M., K. Inaba, Y. Fukuba, S. Mori, H. Haruna, H. Doi, Y. Adachi,
H. Iwai, N. Hosaka, and H. Hisha. 1995. Activation of thymic B cells by signals of CD40 molecules plus interleukin-10. Eur. J. Immunol. 25:1244-1248.

30. Koopman, G., C.P. Reutelingsperger, G.A. Kuijten, R.M. Keehnen, S.T. Pals, and M.H. Van Oers. 1994. Annexin V for flow cytometric detection of phosphatidylserine expression on B cells undergoing apoptosis. Blood. 84: $1415-1420$.

31. Vermes, I., C. Haanen, H. Steffens-Nakken, and C. Reutelingsperger. 1995. A novel assay for apoptosis. Flow cytometric detection of phosphatidylserine expression on early apoptotic cells using fluorescein labeled annexin V. J. Immunol. Methods. 184:39-51.

32. Parham, P., C.J. Barnstable, and W.F. Bodmer. 1979. Use of a monoclonal antibody (W6/32) in structural studies of HLA-A,B,C, antigens. J. Immunol. 123:342-349.

33. Watson, A.J., R. DeMars, I.S. Trowbridge, and F.H. Bach. 1983. Detection of a novel human class II HLA antigen. Nature. 304:358-361.

34. Kayagaki, N., A. Kawasaki, T. Ebata, H. Ohmoto, S. Ikeda, S. Inoue, K. Yoshino, K. Okumura, and H. Yagita. 1995. Metalloproteinase-mediated release of human Fas ligand. J. Exp. Med. 182:1777-1783.

35. Banchereau, J., P. De Paoli, A. Valle, E. Garcia, and F. Rousset. 1991. Long-term human B cell lines dependent on interleukin-4 and antibody to CD40. Science. 251:70-72.

36. Schwartz, R.H. 1990. A cell culture model for T lymphocyte clonal anergy. Science. 248:1349-1356.

37. Gimmi, C.D., G.J. Freeman, J.G. Gribben, G. Gray, and L.M. Nadler. 1993. Human T-cell clonal anergy is induced by antigen presentation in the $a b-$ sence of B7 costimulation. Proc. Natl. Acad. Sci. USA. 90:6586-6590.

38. Tan, P., C. Anasetti, J.A. Hansen, J. Melrose, M. Brunvand, J. Bradshaw, J.A. Ledbetter, and P.S. Linsley. 1993. Induction of alloantigen-specific hyporesponsiveness in human $\mathrm{T}$ lymphocytes by blocking interaction of CD28 with its natural ligand B7/BB1. J. Exp. Med. 177:165-173.

39. Dranoff, G., E. Jaffee, A. Lazenby, P. Golumbek, H. Levitsky, K. Brose, V. Jackson, H. Hamada, D. Pardoll, and R.C. Mulligan. 1993. Vaccination with irradiated tumor cells engineered to secrete murine granulocyte-macrophage colony-stimulating factor stimulates potent, specific, and long-lasting antitumor immunity. Proc. Natl. Acad. Sci. USA. 90:3539-3543.

40. Chen, L., S. Ashe, W.A. Brady, I. Hellstrom, K.E. Hellstrom, J.A. Ledbetter, P. McGowan, and P.S. Linsley. 1992. Costimulation of antitumor immunity by the $\mathrm{B} 7$ counterreceptor for the T lymphocyte molecules CD28 and CTLA-4. Cell. 71:1093-1102.

41. Townsend, S.E., and J.P. Allison. 1993. Tumor rejection after direct costimulation of CD8 + T cells by B7-transfected melanoma cells [see comments]. Science. 259:368-370.

42. Cardoso, A.A. J.L Schultze, V.A. Boussiotis, G.J. Freeman, M.J. Seamon, S. Laszlo, A. Billet, S.E. Sallan, J.G. Gribben, and L.M. Nadler. 1996. Pre-B acute lymphoblastic leukemia cells may induce T-cell anergy to alloantigen. Blood. 88:41-48.

43. Schultze, J.L., M.J. Seamon, S. Michalak, J.G. Gribben, and L.M. Nadler. 1997. Autologous tumor infiltrating T cells cytotoxic for follicular lymphoma cells can be expanded in vitro. Blood. 89:3806-3816. 